\title{
Obstetric violence according to obstetric nurses
}

\author{
Violência obstétrica na visão de enfermeiras obstetras
}

\author{
Violencia obstétrica en la visión de enfermeras obstetras
}

Michelle Gonçalves da Silva ${ }^{1}$, Michelle Carreira Marcelino ${ }^{2}$, Lívia Shélida Pinheiro Rodrigues ${ }^{1}$, Rosário Carcaman Toro $^{3}$, Antonieta Keiko Kakuda Shimo ${ }^{1}$

The objective was to report the experience of obstetric nurses on the obstetric violence experienced, witnessed and observed during their professional careers. This study is based on an account of experience of working in several health institutions such as basic health units, private and public hospitals, located in São Paulo, Brazil, in a period 5-36 years of technical training and professional experience from 1977 to 2013. The technique to expose the professional experiences was brainstorming. The results were divided into violent utterances of health professionals to patients, unnecessary and/or iatrogenic experiences procedures performed by health professionals and the institutional unpreparedness with unstructured environment. It is concluded that through the speeches of the obstetric nurses there are several obstetric violence experienced and witnessed in their work routines, with differences between two types of delivery care: evidence-based obstetrics and traditional care model.

Descriptors: Violence Against Women; Gender and Health; Humanizing Delivery; Obstetric Nursing.

Objetivou-se relatar a experiência de enfermeiras obstetras sobre a violência obstétrica vivenciada, presenciada e observada durante suas trajetórias profissionais. Este estudo baseia-se em um relato de experiência na atuação em diversas instituições de saúde, como unidade básica de saúde, hospitais privados e públicos, localizados no município de São Paulo/Brasil, em um período de 5 a 36 anos de formação técnica e atuação profissional de 1977 a 2013 . A técnica para expor as experiências foi a de "tempestade de ideias". Os resultados encontrados foram divididos em verbalizações violentas dos profissionais de saúde às pacientes, procedimentos desnecessários e/ou iatrogênicos realizados pelos profissionais de saúde e o despreparo institucional com ambientes desestruturados. Concluiu-se, por meio das falas das enfermeiras obstetras, inúmeras violências obstétricas vivenciadas e presenciadas em suas rotinas de trabalho, havendo diferenças entre dois tipos de assistência ao parto: a obstetrícia baseada em evidências e o modelo assistencial tradicional.

Descritores: Violência Contra a Mulher; Gênero e Saúde; Parto Humanizado; Enfermagem Obstétrica.

El objetivo fue relatar la experiencia de enfermeras obstetras sobre la violencia obstétrica vivenciada, presenciada y observada durante sus carreras profesionales. Este estudio se basa en un relato de experiencia de trabajo en diversas instituciones de salud, como unidad básica de salud, hospitales privados y públicos, en São Paulo/Brasil, en un período de 5 a 36 años de formación técnica y actuación profesional de 1977-2013. La técnica para exponer las experiencias profesionales fue la "tempestad de ideas". Los resultados se dividieron en expresiones violentas de profesionales de salud a las pacientes, procedimientos innecesarios e/o iatrogénicos por profesionales de salud y falta de preparación institucional con entornos no estructurados. En conclusión, a través de las hablas de las enfermeras obstetras, inúmeras violencias obstétricas vivenciadas y presenciadas en sus rutinas de trabajo, con diferencias entre dos tipos de atención al parto: la obstetricia basada en evidencias y el modelo de atención tradicional.

Descriptores: Violencia Contra la Mujer; Género y Salud; Parto Humanizado; Enfermería Obstétrica.

\footnotetext{
${ }^{1}$ Universidade Estadual de Campinas. São Paulo, SP, Brazil.

${ }^{2}$ Universidade de São Paulo. São Paulo, SP, Brazil.

${ }^{3}$ Universidad de Concepción. São Paulo, SP, Brazil.

Corresponding author: Antonieta Keiko Kakuda Shimo

Rua Tessália Vieira de Camargo, 126, Cidade Universitária “Zeferino Vaz”, CEP: 13084-971. Campinas, SP, Brazil. E-mail: akkshimo@fcm. unicamp.br
} 


\section{Introduction}

Maternity is perceived by some women as the beginning of a new cycle, a differential landmark, which consecrates the scope of the feminine role, although most of the patients associate it to intense pain and suffering, being a moment of great expectation. Although it is physiological, delivery can suffer interferences from the emotional condition, from culture, from values, from the history of the mother in labor and from environmental factors ${ }^{(1)}$.

One in every four Brazilian women suffers violence during labor according to a research made in 2010 by Fundação Perseu Abramo: 'Brazilian women and gender in private and public venues'. The international concept in labor defines any act or intervention directed to the women in labor or her baby, practiced without the explicit and informed consent of the woman and/or in disrespect to her autonomy, physical and mental integrity, her feelings, options and preferences ${ }^{(2)}$.

The body integrity of the women and their emotional welfare do not seem to be relevant outcomes for the public health system; the national investigations on the satisfaction of the women concerning the experience of giving birth are still scarce. From another perspective and measure, the disrespect and abusing by part of the health professionals against the women during pregnancy and in labor, was also proved by the Test of Obstetric Violence, answered by almost two thousand women in March and April, 2012, in which half of them reported to be dissatisfied with the quality of the medical and hospital care received for the birth of a child ${ }^{(3)}$.

As strategy to confront this Brazilian reality, the Health Department developed the Program of Safe Maternity which is aimed at respecting the human dignity, the feelings, the choices and preferences of all the women, therefore, it is more than the prevention of deaths and morbidities but the development of a holistic look on the women, covering all the feminine bio-psychosocial ${ }^{(4)}$.
When directing the obstetric care before, during and after labor, we must know that every woman has the legal right to: receive free treatment caused by damages and ill-treatments, obtain information, clarified consent with the possibility of refusal and guarantee regarding their choices and preferences, including an accompanying person during the whole period of hospitalization in the obstetric unit, privacy and secrecy, be treated with dignity and respect, receive equal treatment, free of discrimination and with equitable attention, receive professional care and have access to the highest possible level of health with freedom, autonomy, self-determination and noncoercion $^{(5)}$.

Disrespecting and abusing during pre-natal exams and delivery are violations of the basic human rights of the women. All these rights are based on instruments of internationally established human rights, including: Universal Declaration of the Human Rights; Universal Declaration on Bioethics and Human Rights; International Pact on Economic, Social and Cultural Rights; International Pact on Civil and Political Rights; Convention on the Elimination of All Kinds of Discrimination against Women; Declaration on the Elimination of Violence against Women; Report of the United Nations High Commission for the Human Rights on the Prevention of Maternal Morbidity/Mortality and Human Rights; Declaration and Platform of Action of the IV World Conference of the United Nations on Women, Beijing 1994(6).

So that the women in labor can be assisted in this peculiar moment of her life, it is up to the health professionals to provide the creation and use of systematized scientific knowledge directed to the individual need. For example, we can mention the legal and basic instruments which prepare the nurses for the development of a holistic and respectful care, making the assistance to the pregnancy puerperal cycle with less medicine as their education teaches ${ }^{(7-8)}$.

Childbirth can be perceived by the woman as being anguishing, once, from the moment she is hospitalized in a maternity ward, she stops 
having control of the situation, everything becomes unpredictable and non-familiar. The woman asks for the comprehension of the health professionals surrounding her, and in general this happens with the nurse $\mathrm{e}^{(9-10)}$.

The acting of the obstetric nurse during the delivery of low risk or common risk can be a measure able to reduce unnecessary interventions during delivery, offering a more complete care to the woman and her family ${ }^{(11)}$. Through the Ordinance of the Health Department no. 2815/98, as of May 29 $9^{\text {th }}, 1998$, the Health Department included the procedure 'delivery without dystocia' or normal delivery in the System of Hospital Information of the Unified Health System, made by the obstetric nurse, assuring her autonomy in the obstetric care ${ }^{(12)}$.

Facing the explicited concept, the authors became aware of the need of changes in this Brazilian reality, that is, the care model. They got together to discuss this important and current theme and share their experiences on obstetric violence they witnessed during their individual professional lives, bringing data and identifying the needs of changes.

The objective of this study was to report the experience of obstetric nurses on obstetric violence, witnessed and observed during their professional lives.

\section{Method}

Report of the experiences of the authors in their professional lives built in different working venues, time and type of education. Worried with the theme and according to the daily experienced situations, the authors decided to develop the present study.

The working venues which characterized these professional experiences are in the county of São Paulo, SP, Brazil: Health Basic Unit, public and/or private hospitals (the public hospitals joined states and counties services) and Social Organizations of Health. As to the hospital sectors where these experiences took place, the following ones are highlighted:
Obstetric Center, Center of Normal Delivery, Maternity Ward and/or Rooming and Nursery.

The participant nurses had education as follows: Specialization in Obstetric Nursing, Residency in Obstetric and Neonatal Nursing and Degree in Obstetrics.

The time of working of these obstetric nurses in a key point for the reflection of the professional life on the assistance rendered during pregnancy, delivery and puerperium. This period was from 5 to 36 years working in Obstetrics, from 1977 to 2013.

The technique to show the experience was brainstorming, a moment of presentation of opinions, reflections and experiences gone through by each one regarding the theme under discussion. The reports were recorded and later on transcript for analysis. This collection occurred in only one meeting of approximately six hours in September, 2013, the categorization and the analysis were made along five meetings between the end of the year of 2013 and the first semester of 2014, coordinated by the guiding and main author.

The data were treated according to the Technique of Analysis of Thematic Content, which represents a set of techniques of analysis of communication, using systematic and objective procedures of description of the content of the reports, through the following stages: 1) Pre-analysis: also called 'fluctuating reading', a moment in which the material is organized and the hypothesis and guiding questions are made; 2) Exploration of the material: it is the organized codification of the gross data into units, through three stages, as follows: a) clipping: choice of the units of register, b) enumeration: the selection of counting rules and c) classification and aggregation: choice of categories and 3) Treatment of the results: it is the moment of inference and interpretation ${ }^{(13)}$.

After the process of the described stages and for a better contextualization and interpretation of the data brought during the meeting of the authors on that theme, the results are presented in three themes: utterances of health professionals to patients; 
unnecessary and/or iatrogenic procedures made by the health professionals; and the institutional unpreparedness for the humanized delivery.

Aiming at the ethical and legal precepts of the research with human beings, we state that no information within this study comes from the experience of third parties; therefore the authors themselves are protagonists of the study.

\section{Results}

Violent utterances from health professionals to patients (Figure 1). Unnecessary and/or iatrogenic procedures made by the health professionals (Figure 2) and Institutional unpreparedness for the humanized delivery (Figure 3).

\begin{tabular}{|c|c|}
\hline Professional category & Violent sentences \\
\hline Doctor and obstetric nurse & $\begin{array}{l}\text { Doing it you didn't scream! } \\
\text { The one who got in has to get out! } \\
\text { It's better if your husband watches the delivery; otherwise he will become disgusted with you! }\end{array}$ \\
\hline Doctor & $\begin{array}{l}\text { When you doing it, it was good, wasn't it?... now you have to stand it! } \\
\text { Don't scream... your baby is not going to be born through your mouth'! } \\
\text { You didn't ask for it... now you have to stand it! } \\
\text { Why aren't you going to have the baby in your town? } \\
\text { Look, your delivery was made by a nurse... I am a doctor... and I have got nothing to do with it... now } \\
\text { if you have complications the blame is the nurse's and yours! } \\
\text { Turn off the light??? Is this a delivery or a Mexican soap opera? } \\
\text { Scheduling the cesarean... you can choose the day and the time of your delivery honey! } \\
\text { It's better to have a cesarean... once the normal delivery frays apart the vagina and so you can preserve } \\
\text { your sexual relations and give more pleasure to your husband! } \\
\text { Let's have a cesarean for the world evolved and you don't have to foal like an animal with discomfort } \\
\text { and a lot of pain... with cesarean you won't have any discomfort! }\end{array}$ \\
\hline Obstetric nurse & $\begin{array}{l}\text { Open up your legs, otherwise you're going to crush the baby's head! } \\
\text { Don't scream, otherwise the baby goes up! }\end{array}$ \\
\hline $\begin{array}{l}\text { Doctor, obstetric nurse and } \\
\text { nursing assistant }\end{array}$ & $\begin{array}{l}\text { If you don't make an effort... your baby is going to die and the blame is yours! } \\
\text { You are hospitalizing one to be on the safe side! } \\
\text { The woman is really a shameless animal... suffers and screams and next year she is here again! }\end{array}$ \\
\hline Doctor and nursing assistant & Keep quiet, otherwise it's going to hurt more! \\
\hline
\end{tabular}

Figure 1 - Violent utterances of the different health professionals who assisted the patients 


\begin{tabular}{|c|c|}
\hline Professional category & Unnecessary and/or iatrogenic procedures \\
\hline Doctor & $\begin{array}{l}\text { Opening of right lateral medium episiotomy after the detachment of the newborn for the Medicine interns to } \\
\text { learn how to do episiorrhaphy; } \\
\text { Routine forceps delivery for the learning of Medicine students; } \\
\text { Routine and non-selective episiotomy; } \\
\text { Lie to the patient as to her dilatation or fetal vitality to appoint cesarean due to trips or private appointments; } \\
\text { Appointment and making the elective cesareans with } 36 \text { weeks before prolonged holydays, Christmas and } \\
\text { New Year's Eve; } \\
\text { Cutting off a finger of the newborn and cuts on the head made by the scalpel during the opening of the uterine } \\
\text { cavity in the cesarean; } \\
\text { Making the cesarean of a 5-month-old fetus due to miscalculation of pregnancy time; } \\
\text { Women in labor with family planning and authorization for tubal ligation, with scheduled cesarean due to } \\
\text { interactivity and the doctor, aware of everything forgot to make the sterilization and the patient was only } \\
\text { informed after hospital discharge; } \\
\text { Elective cesarean delivery forging indications which are not real (fetal macrosomia, meconium, circular } \\
\text { cervical, maternal narrow basin, among others); } \\
\text { Performing perineal shaving and fleet enema antepartum; } \\
\text { Keep the woman in labor in a prolonged fast without clinical justification; } \\
\text { Fast for elective cesarean and uterine curettage, over } 12 \text { hours; } \\
\text { Tie the legs to the gynecological table during normal delivery; } \\
\text { Obstetric emergency care appointment without the doctor's introduction and being impatient not to allow } \\
\text { the patient to utter her complaints and telling her to take off her panties and lie down to be examined; } \\
\text { Deny providing pre-natal card to the pregnant woman; } \\
\text { Not allowing the skin to skin contact after the birth of vigorous and healthy babies for being in a hurry to } \\
\text { examine them; } \\
\text { Make oral-tracheal intubation in the vigorous newborn in the delivery room to lower Apgar's score and } \\
\text { promote discrediting of the work of the obstetric nurses in normal deliveries; } \\
\text { Impatient anesthesiologist patted the patient waist and uttered bad words due to her moving in the } \\
\text { contractions during spinal anesthesia. }\end{array}$ \\
\hline $\begin{array}{l}\text { Doctor and obstetric } \\
\text { nurse }\end{array}$ & $\begin{array}{l}\text { Excessive traction of the umbilical cord to remove the placenta; } \\
\text { Not allowing the right of the accompanying person during the delivery; } \\
\text { Physical examination without permission or previous personal introduction of the health professional and } \\
\text { explanation of the procedure; } \\
\text { Collective vaginal touches for technical education; } \\
\text { Digital cervical reduction; } \\
\text { Kristeller's technique to anticipate birth; } \\
\text { Routine amniotomy; } \\
\text { Use of synthetic hormones in a routine manner and without criteria to anticipate delivery, exposing the } \\
\text { binomial to unnecessary discomfort, pain and risks ; } \\
\text { Not allowing the patient to choose the best position for delivery; } \\
\text { Physical examination without privacy and exposition of the patient to other patients and accompanying } \\
\text { persons. }\end{array}$ \\
\hline $\begin{array}{l}\text { Doctor, obstetric nurse } \\
\text { and nursing assistant }\end{array}$ & $\begin{array}{l}\text { Refer to the patient using the bed number, the pathology, centimeters of dilatation, parity and not using her } \\
\text { name; } \\
\text { Discrimination concerning the ethnic group of the woman in labor; } \\
\text { Rude assistance and angry health professionals. }\end{array}$ \\
\hline Obstetric nurse & $\begin{array}{l}\text { Exposition of names and diagnosis of the women in labor in panels in the halls; } \\
\text { Deficient organization in the distribution of beds leaving the patients as victims of abortion and fetal death } \\
\text { together with pathological pregnant women, women in labor or newly delivered mother going through } \\
\text { maternal breastfeeding. }\end{array}$ \\
\hline $\begin{array}{l}\text { Doctor, nurse and } \\
\text { obstetric nurse }\end{array}$ & $\begin{array}{l}\text { During the pre-natal exams do not prepare the pregnant woman for the delivery as well as for breastfeeding, } \\
\text { not providing any kind of information, whether through verbal orientation, groups of pregnant women or } \\
\text { information material ; } \\
\text { Not filling in the pre-natal card correctly. }\end{array}$ \\
\hline $\begin{array}{l}\text { Doctor, nurse and } \\
\text { nursing assistant }\end{array}$ & Provide artificial milk or water with glucose at night, so that the baby can calm down and sleep better. \\
\hline $\begin{array}{l}\text { Nurse and nursing } \\
\text { assistant }\end{array}$ & $\begin{array}{l}\text { Use the glove finger as a pacifier to calm down the baby and so improve the hearing comfort of the health } \\
\text { professional. }\end{array}$ \\
\hline Doctor and nurse & le strict times for the mothers to visit their babies in the neonatal intensive therapy unit. \\
\hline
\end{tabular}

Figure 2 - Unnecessary and/or iatrogenic procedures made by the health professionals 


\begin{tabular}{|l|l|}
\hline $\begin{array}{l}\text { Hospital } \\
\text { structure }\end{array}$ & \multicolumn{1}{|c|}{ Institutional unpreparedness } \\
\hline $\begin{array}{l}\text { Physical } \\
\text { structure }\end{array}$ & $\begin{array}{l}\text { Lack of room and minimum comfort for the } \\
\text { accommodation of the accompanying persons. }\end{array}$ \\
\hline Equipment & $\begin{array}{l}\text { Outdated delivery tables for a humanized } \\
\text { assistance, on which the women can only } \\
\text { deliver in the lithotomic position. }\end{array}$ \\
\hline Ambience & $\begin{array}{l}\text { Poorly ventilated environments; } \\
\text { Intense artificial lighting; } \\
\text { Inadequate natural lighting; } \\
\text { Lack of institutionalization of rooming. }\end{array}$ \\
\hline Management & $\begin{array}{l}\text { Lack or non-compliance with obstetric } \\
\text { protocols aimed at the humanization of the } \\
\text { assistance in the pregnancy and puerperal } \\
\text { cycle; } \\
\text { Lack of periodic training of all the workers } \\
\text { committed in the assistance. }\end{array}$ \\
\hline
\end{tabular}

Figure 3 - Institutional unpreparedness for the humanized delivery

\section{Discussion}

At the time of delivery, the major need of the women is the emotional support ${ }^{(14)}$. The delivery is a physiological process which has the beginning and evolution by itself: the cervix of the uterus begins to open, the uterus is contracted the baby begins to come down, and everything becomes more intensive, until the moment of the birth itself. All this process can happen in a comfortable and safe manner, without interventions. The uterus contractions, the liberation of hormones and the passage through the vagina favor the final ripening of the baby, the expelling of lung liquids and a better adaptation to the world ${ }^{(8)}$.

The obstetric care based on evidence is the one which provides assistance, support and protection, with a minimum of necessary interventions ${ }^{(15)}$. Analyzing the three themes of results, we observed unpreparedness, negligence and malpractice of the obstetric nurses or nursing assistants. The violence practiced by obstetrics nurses, whose basis of education should be holistic and humanized, is surprising ${ }^{(7)}$. It leads to the reflection on how these health professionals are being educated.
Another condition favoring the obstetrics violence observed during our discussion was the lack of institutional hospital care, even in the Brazilian state that is considered the most developed one, which is São Paulo, in most variations: physical structure, structure with trained personnel and structure of assistance guidelines. The Brazilian hospital must be suit the human rights of the women in their gravidic puerperal cycle, leaving those traditional and outdated structures behind and promoting more favorable ambience to the holistic work of the health professionals, granting a more dignified assistance to the woman and her newborn ${ }^{(16)}$. A good alternative for this improvement is the construction of Normal Delivery Centers, once their working records have the best perinatal results for normal, physiologic deliveries and the ones with occasional risk ${ }^{(17)}$.

The obstetric assistance without scientific support is aggressive and in many cases violates the basic human rights of the women and it is linked to the model of the current delivery as the results show. The model is supported by a scant system of educations and health, which does not provide adequate inspection of the institutions of education and health, even when all the indicators of maternal and neonatal health diverge of those recommended by science and the organs of regulation.

The Pesquisa Nascer in Brazil (a research concerning childbirth): an inquiry of delivery and birth clarifies the most recent data of our nation and shows that delivery in our country is each time more violent, with high and increasing cases of the use of synthetic oxytocin, episiotomy, actions to anticipate birth and cesareans without justification ${ }^{(18)}$.

We believed that the obstetric nursing can make a big difference in these postural and violent behaviors of the current obstetric assistance, which has been going on since the beginning of the $20^{\text {th }}$ century, when delivery was institutionalized, once, according to the World Health Organization, and confirmed by Health Department through its current program of humanization of the 'Rede Cegonha', it is the most well 
prepared professional category for the change of this Brazilian record and for the consolidation of a safe assistance to the process of delivery and birth ${ }^{(4,19)}$.

A starting step was taken for the re-learning of the professional technicians in obstetrics and training of new professionals is in the scientific knowledge, whose results encourage us to trust in the physiology of the female body and in her natural condition to deliver and supply legal and scientific support for the adoption of possible and necessary procedures before, during and after delivery ${ }^{(20)}$.

Concerning the violent and disrespectful sentences from our registers, we find studies which show that the major need for a woman in labor is in the management of her emotional control, once the women report as a determining factor for a positive delivery experience, the trust in the team which provides assistance and they highlight the importance of caress, patience and calmness by the health professionals, but what these women do not know is that humanized attention must be a technical ability inherent to obstetrics ${ }^{(21)}$.

However, we believe that this humanization must stand in the first pre-natal appointment once the pregnant woman who has received a good preparation in this stage through adequate orientation, participation and reflection of informative material, are more prepared for the hospitals: emotionally, socially, physically and they have better knowledge of their legal rights, so that the assistance to delivery and, puerperium is made more easily and less stressful $^{(22-23)}$.

A good example of good obstetric practice is the seven steps proposed by the 'The guidebook of the Gender, Violence and Human Rights Project', in which the modern Obstetric Nursing can reflect itself (24): 1)Explain to the patient, in a way so that she can understand what you think she has, what you can do for her, and how she can help. Promote the right to the condition of the patient as subject of the relation; 2) Know and respect the scientific evidences. Avoid invasive, painful and risky procedures, unless they are strictly indicated. Help to promote the right of the women to their body integrity and to enjoy the progresses of science; 3) Although your working conditions are sometimes hard, treat the patient as a person, with the due respect. If you do not have time to listen to her, try to work together with your colleagues at the health service. Promote the right to the condition of the person in order for her to be free of a humiliating treatment; 4) Recognize and promote the right of the patients to have an accompanying person of her choice during the pre-natal and delivery period. Researches show that this is the one of the most effective procedures to improve the quality of the assistance; 5) Promote the right to the access to her bed and to the equity in the assistance; 6) Inform the woman about her rights regarding maternity and reproduction; and 7) Invest on yourself, look for more satisfaction and achievement in your work. Try to update and recycle yourself. You are not alone: join a net of assistance to humanized delivery.

\section{Final Considerations}

Through the report of experience of five working and experienced obstetric nurses, we can consider that there are several obstetric violences, witnessed and experienced by them in their professional trajectories and that there is difference between the two types of assistance to delivery: the Obstetric based on evidences and the traditional, technocratic, standardized and ordinary hospital mode, the one you will find everywhere: public, private and mixed maternity wards, except rare exceptions.

Therefore, it is necessary to have changes in the model of obstetric assistance, in the syllabus during the education of the technical professional in obstetrics, especially concerning Obstetric Nursing, in order to have a differentiation of the traditional medical education, a fact that has been occurring for many years and can be proved by the different years of education and experience of each author.

But as working and activist professionals, 
we cannot stop believing that the Obstetric Nursing can update its knowledge under the light of the best scientific evidences currently available and so guarantee that the patients enjoy the advancement of those researches.

It is observed that there is concern of the government, once the Health Department, through its technical area in Health of the Woman, together with the Department of Education and Science, has been encouraging them through funds to the institutions of the universities for the education of obstetric nurses, whether for specialization lato sensu or internship, therefore glimpsing a leap of quality in the assistance to the woman in the process of pregnancy, delivery and puerperium and also an increase in the contingent of professionals aligned with 'Rede Cegonha' (The Stork Network).

\section{Collaborations}

Silva MG participated in the conception, analysis, interpretation of the data and final approval of the version to be published. Marcelino MC, Rodrigues LSP and Toro RC participated in the conception, interpretation of the data and writing of the article. Shimo AKK participated in the analysis, interpretation of the data and final approval of the version to be published.

\section{References}

1. Gallo RBS, Santana LS, Marcollin AC, Ferreira $\mathrm{CHJ}$, Duarte A, Quintana SM. Recursos nãofarmacológicos no trabalho de parto: protocolo assistencial. Femina. 2011; 39(1):41-8.

2. Venturi W, Bokany V, Dias G, Alba D, Rosas W, Figueiredo N. Mulheres brasileiras e gênero nos espaços públicos e privado. Fundação Perseu Abramo e SESC [Internet]. 2010 [citado 2013 mar 21]. Disponível em:http://novo.fpabramo.org.br/ sites/default/files/pesquisaintegra_0.pdf

3. Dip A. Na hora de fazer não gritou. Agência de Reportagem e Jornalismo Investigativo [Internet].
2012 [citado 2013 mar 25]. Disponível em: http:// www.apublica.org/2013/03/na-hora-de-fazernao-gritou/

4. Ministério da Saúde (BR). Manual Prático para Implementação da Rede Cegonha. Brasília: Ministério da Saúde; 2011.

5. Dailys GJ, Zoe DB, Marlen AA. Childbirth of medically supervised delivery from an anthropological perspective. Cienc Saúde Coletiva. 2012; 17(7):1893-902.

6. Frenkel LA, Stinger G, Gray A. A guide for advocating for respectful maternity care.the white ribbon alliance [Internet]. 2013 [cited 2013 Sept 30]. Available from: http://whiteribbonalliance. org/wp-content/uploads/2013/10/RMC-Guide_ FINAL.pdf

7. Campos ACS, Cardoso MVLML, Pagliuca LMF, Rossi LA. Comunicação: instrumento básico de enfermagem para cuidar da mãe do neonato sob fototerapia. Rev Rene. 2008; 9(4):24-32.

8. Carvalho VF, Kerber NPC, Busanello J, Gonçalves BG, Rodrigues EF, Azambuja EP. How the workers of a birthing center justify using harmful practices in natural childbirth. Rev Esc Enferm USP. 2012; 46(1):29-35.

9. Silva LM, Barbieri M, Fustinoni SM. Vivenciando a experiência da parturição em um modelo assistencial humanizado. Rev Bras Enferm. 2011; 64(1):60-5.

10. Carvalho VF, Kerber NPC, Busanello J. Costa MMG, Gonçalves BG, Quadros VF. Práticas prejudiciais ao parto: relato dos trabalhadores de saúde do sul do Brasil. Rev Rene. 2010; 11(n. esp.):92-8.

11. Carvalho FAM, Pinheiro AKB, Ximenes LB. Assistir à parturiente: uma visão dos acadêmicos de enfermagem. Rev Rene. 2010; 11(1):86-93.

12. Ministério da Saúde (BR). Portaria n. 2815/98. Institui o procedimento de parto normal realizado por enfermeiro obstetra no Sistema Único de Saúde. Brasília: Ministério da Saúde;1998.

13. Bardin L. Análise de conteúdo. Lisboa: Edições 70; 2011.

14. Hodnett ED, Gates S, Hofmeyr GJ, Sakala C, Weston J. Continuous support for women during childbirth. Cochrane Database Syst Rev. 2011; 16(2):CD003766. 
15. World Health Organization (WHO). More midwives needed to improve maternal and newborn survival. Bull Word Health Organ. 2013; 91:804-5.

16. Riesco MLG, Oliveira SMJV, Bonadio IS, Schneck CA, Silva FMB, Diniz CSG, Lobo SF, Saito E. Centros de parto no Brasil: revisão da produção científica. Rev Esc Enferm USP. 2009; 43(Esp2):1297-302.

17. Basile ALO, Pinheiro MSB, Miyashita NT. Centro de parto normal intra-hospitalar.1 ${ }^{\mathrm{a}}$ ed. São Caetano do Sul: Yendis; 2010.

18. Escola Nacional de Saúde Pública. Inquérito Epidemiológico sobre as conseqüências do parto cesárea desnecessário no Brasil. Projeto Nascer no Brasil. [Internet]. 2011 [citado 2013 maio 1]. Disponível em: http//www.ensp. fiocruz.br/portal-ensp/informe/site/materia/ detalhe/29584

19. Organização Mundial de Saúde (OMS). Assistência ao parto normal: um guia prático. Relatório de um grupo técnico. Genebra: OMS/SRF/MSM; 1996.

20. World Health Organization (WHO).Care in Normal Birth: a practical guide [Internet]. Bull
Word Health Organ; 2012 [cited 2013 sept 8] Available from:http://apps.who.int/iris/ bitstream/10665/77764/1/9789241504843_ eng.pdf

21. Larsson BW, Bojo AKS, Starrin B, Larsson G. Birthgiving women's feelings and perceptions of quality of intrapartal care: anationwide Swedish cross-sectional study. JCN. 2011; 20(2):1168-77.

22. Maia MB. Humanização do parto: política pública, comportamento organizacional e ethos profissional. Rio de Janeiro: Fiocruz; 2010.

23. Santos MRC, Zellerkraut H, Oliveira LR. Curso de orientação à gestação: repercussões nos pais que vivenciam o primeiro ciclo gravídico. Mundo Saúde. 2008; 32(4):420-9.

24. Diniz CSG. "O que nós profissionais de saúde podemos fazer para promover os direitos humanos das mulheres na gravidez e no parto". Cartilha do Projeto Gênero, Violência e Direitos Humanos - Novas questões para o campo da saúde. São Paulo: USP; 2010. 